\title{
Changes in Some Aspects of Teachers' Work in the Czech Republic Since 1989
}

\section{Zmiany w niektórych obszarach pracy nauczycieli w Czechach po 1989 roku}

\begin{abstract}
In recent decades, society has fundamentally changed; there are political changes affecting education and, consequently, demands on teachers' work change, as well as parents' and society's expectations of teachers. The main aim of this qualitative research is to map the changes in the conditions of teachers' work in the Czech Republic in the last thirty years according to the subjective perception of teachers-experts, i.e. respondents. The respondents are teachers who have been active in the profession for at least thirty years. All the respondents are women working as primary school teachers (Dáša, Lucie, Jana, Danka, Blanka, Dominika, Karolína).

In the research we deal with the following areas: interpersonal relationships at the workplace, communication and cooperation with pupils' parents, and the teacher-pupil relationship.

The most important results of this research are as follows. The respondents are aware of and perceive the decreasing authority of the teacher today. They point out that the teacher's authority has degraded in the eyes of pupils, parents, and society. The most widespread problem faced by teachers is the disruptive behavior of pupils, which may interfere with teaching.
\end{abstract}

KEYWORDS

qualitative research, teachers-experts, changes, interpersonal relationships at the workplace, communication and cooperation with pupils' parents, teacher-pupil relationship

\section{SLOWA KLUCZOWE}

badania jakościowe, nauczyciele-eksperci, zmiany, relacje interpersonalne w miejscu pracy, komunikacja i współpraca z rodzicami uczniów, relacja nauczyciel-uczeń

SPI Vol. 23, 2020/3 ISSN 2450-5358 e-ISSN 2450-5366 DOI: 10.12775/SPI.2020.3.004

Submitted: 03.03.2020 Accepted: 26.05 .2020

Miscellanea 
Moreover, today's teachers sometimes have to deal with parents who are completely uncritical of their children, whom they trust completely. When problems arise, these parents never see the root cause in their child but in other classmates or, most frequently, in the teacher. If a child receives a bad grade, these parents are willing to go to the teacher and try to find the error on their side rather than in their own children.

\section{ABSTRAKT}

W ostatnich dziesięcioleciach społeczeństwo uległo zasadniczej zmianie. Dokonuja się zmiany polityczne, które wpływają na edukację, a co za tym idzie, na wymagania dotyczq̨e pracy nauczycieli, a także na oczekiwania rodziców i społeczeństwa wobec nauczycieli. Głównym celem przeprowadzonego badania jakościowego jest opis zmian warunków pracy nauczycieli w Czechach w ciqgu ostatnich trzydziestu lat z perspektywy subiektywnego postrzegania badanych nauczycieli-ekspertów. Badani nauczyciele wykonuja pracuja w zawodzie od co najmniej trzydziestu lat. Wszystkie respondentki to kobiety pracujqce jako nauczycielki w szkołach podstawowych (Dáša, Lucie, Jana, Danka, Blanka, Dominika, Karolína). W badaniach poddano analizie następujqce obszary: stosunki interpersonalne w miejscu pracy, komunikację i współpracę z rodzicami uczniów oraz relację nauczyciel-uczeń.

Badania doprowadziły do następujqcych najważniejszych wniosków: respondenci sq dziś świadomi zachodzqcych zmian i dostrzegaja spadek autorytetu nauczyciela; wskazują na obniżanie się autorytetu nauczyciela w oczach uczniów, rodziców i społeczeństwa; najbardziej rozpowszechnionym problemem, z którym borykaja się nauczyciele, sq destrukcyine zachowania uczniów, które moga przeszkadzać w nauczaniu.

Co więcej, dzisiejsi nauczyciele czasami mają do czynienia z rodzicami, którzy sq całkowicie bezkrytyczni wobec swoich dzieci i ufajq im bezrefleksyjnie. Kiedy pojawiaja się problemy, rodzice ci nigdy nie widzq głównej przyczyny w swoim dziecku, ale w innych kolegach z klasy lub najczęściej w nauczycielu. Jeśli dziecko otrzyma złą ocenę, rodzice ci sq skłonni udać się do nauczyciela i próbować wykazać błąd po jego stronie, a nie we własnych dzieciach. 


\section{Changes in Czech schools since 1989}

Political and social changes since 1989 have brought about the transformation of the education system, which was to correspond with the progressive tendencies of the Western European education system and, at the same time, to return to the pre-war traditions of the Czech education system. Radical structural, administrative, curricular, and funding changes have been introduced into the education system (Fasnerová 2009).

In 1994, the Ministry of Education, Youth, and Sports of the Czech Republic drew up the document "Program for the Development of the Education System of the Czech Republic - Quality and Responsibility," which laid the foundation for the reform of the Education Act and curriculum policy. Based on this document, the Standard for Primary Education (1999) was created in 1995. In addition, a new system of curricular documents was introduced into the education system. Between 1996 and 1997, three curricula for primary education were approved - the Elementary School, the Primary School, and the National School curricula - which replaced the previously used curricula and plans.

Alternative methods such as Waldorf School, Healthy School, Start Together, Forest School, or Open Teaching also started to be promoted.

Since 1998 home education has been allowed in the Czech Republic, which has been understood since 2005 under the term 'individual education' as an equivalent variant of compulsory first-level primary school attendance and since 2016 also as an equivalent variant of compulsory second-level primary school attendance.

In 2001, the "National Program for the Development of Education - White Paper" was established, which described the way that education in the Czech Republic should be headed and the changes that should be made. This document defined six main objectives of education; it highlights the importance of key competences, emphasizes the need for greater autonomy of schools, and highlights the need to proceed with school reform (Fasnerová 2009).

In 2004, two acts were passed: The Education Act (Act No. 561/2004) and the Act on Educational Staff (Act No. 563/2004). In 2004, the Education Act enacted the creation of Framework 
Educational Programs, on the basis of which school educational programs were created reflecting the specificities of each school.

\section{Changes in the conditions of teachers' work in the light of new research}

Although perceived as conservative subjects, schools should respond to new demands related to socio-economic changes. A school that does not respond to changes related to the development of society leads to destabilization in the education system (Kotásek 2004). On the other hand, stability at school has a positive connotation and imparts a good image of the school, and stability in school management and the teaching strategies used and stability in staffing are also important. Change and stability should therefore be in harmony, because change will bring the necessary innovation and improve the quality of the institution (Vašutová and Urbánek 2010), improve the functioning of the school (Hopkins 2001), while stability manifests itself in the steadfast culture of the school, preserving its tradition (Vašutová and Urbanek 2010).

\section{Attitude of teachers to changes and reforms}

The education of each country, as the German teacher Terhart (2013) says, lags behind the development of society and deserves to be improved. If we identify with this idea, then we must regard reforms as a positive phenomenon, as something beneficial that will raise the level of education. If we perceive the term 'reform' itself as an important term in pedagogy (Terhart 2013) and we agree with the idea that reformation is the correct action (Mareš 2018), then we will be surprised by teachers' attitude to reforms, which is frequently negative; it can even be said that, in some situations, "we are faced with teachers' opposition to school reform” (Mareš 2018). According to Lunenburg (2010), teachers and schools are not in favor of school reforms. If they have a choice, most schools prefer stability over change.

Teachers' opposition to reforms has not been only a recent issue. It is a phenomenon that all school reforms have faced in the past (Terhart 2013). The first research studies mapping this problem appeared after World War II (e.g. Coch and French 1948). 
The attitude of teachers to reforms in the Czech Republic is a little-studied phenomenon. In the Czech Republic, there is no research describing the current state and development trends of teachers' attitudes toward changes in education or teachers' criticism of the proposed changes, and we lack knowledge of the causes of Czech teachers' opposition to change (Mareš 2018; Průcha 2002). It has been noted that some groups of teachers demonstrate teachers' unpreparedness for change, unwillingness to accept it, or lack of cooperation in its implementation (Mareš 2018). According to Lunenburg (2010), social pressure is a serious factor affecting teachers' resistance to change. This phenomenon is described by Lunenberg as the educational situation in which groups of teachers have been established that have set specific standards of behavior that determine the limits to which group members can go. If such a group of teachers is opposed to change, it is difficult for an individual to stand up to the whole group and to promote their own different views and support change.

\section{Changes in the teacher-pupil relationship}

Educational system reforms also brought changes in expectations toward the teacher, their role and approach to the pupils, changes in the pupil's position in the teaching process, and the promotion of the pupil-teacher relationship based on a partnership approach (Poláchová-Vaštátková, Rudnicki et al. 2015).

In research conducted by Urbánek and Vašutová (2010), it was found that teachers describe working with children as increasingly difficult compared to the past. In their statements, teachers reported an increasing number of disciplinary problems and a decrease in pupils' interest in school obligations. Therefore, teachers regularly experience feelings of dissatisfaction, failure, disillusionment, and exhaustion in connection with their work. A research study by Pugnerová and Plevová (2010) found that teachers with longer teaching experience show less job satisfaction, and with increasing lengths of teaching experience, teachers experience greater subjective dissatisfaction due to lack of work success and recognition. In connection with the lower interest of pupils in learning, the research of Straková, Spilková, Simonová, Friedleanderová, and Hanzák (2013) 
reveals teachers mentioning the lower knowledge and skills of pupils, which translates into teachers being less demanding on pupils than they were before. At present, primary school teachers face specific disciplinary problems of pupils which did not exist at primary schools twenty years ago.

The same research survey found that teachers realize that it is becoming increasingly difficult to understand today's children, to attract their attention in class, and to motivate them to fulfill their school duties. Although teachers testify that they are currently required to maintain a relationship with pupils that is based on partnership more than before, they believe that an overly democratic approach disrupts the teacher-pupil relationship and leads to disciplinary problems in the classroom as pupils are not prepared for this approach and abuse it.

\section{Changes in the teacher-parent relationship}

The reforms to the education system since 1989 have also brought changes in the parent-teacher relationship, the school's openness to parents, and changes in parents' expectations of teacher and school, promoting the concept of parents as equal partners (Poláchová-Vaštátková, Rudnicki et al. 2015).

In research conducted by Urbánek and Vašutová (2010), it was found that teachers describe relationships with parents as more complicated than they were before. Teachers are aware of changes in the value preferences and lifestyles of contemporary families.

In a research survey by Straková, Spilková, Simonová, Friedleanderová, and Hanzák (2013), teachers mention that, in the past, parents were more concerned about good learning outcomes of their children, and cooperated more with the school and the teachers, who represented authority for them.

Nowadays, we mostly encounter two approaches in the relationship of parents with the school; these are called the client and the partner approaches (Rabušicová et al. 2004). According to Čapek, these approaches are not mutually exclusive: "The school should treat the parent as a partner in the education of the pupil without forgetting that they are its client whom the school serves. The school must respect that its clients are parents, and if it wants to do its job in the 
best possible way, it must offer them various platforms of cooperation and partnership" (Čapek 2013: 15).

Rabušicová et al. (2004) define four basic roles of parents in relation to school - client, partner, and civic roles, and the parent as a problem role. In the Czech Republic, the client approach has so far prevailed, but it can be expected that the perception of parents as equal partners will gradually increase, as is the case today in other developed European countries (Rabušicová et al. 2004).

\section{Changes in relations among teachers}

The teacher is not an isolated working individual but is expected to work in a team with other members of the teaching staff at school. Teachers who work together effectively bring quality teaching to the school, the development of individual staff members, a positive climate among themselves, and also a positive school-wide climate. The atmosphere among the teaching staff as well as the quality of the teaching staff are influenced by multiple factors. These mainly include the size of the teaching staff, the qualification of teachers, the degree of feminization of the teaching staff, the age structure, the working potential of teachers, and the political, cultural, and linguistic differences of teachers (Voda 2012).

\section{Characteristics of teaching staff}

Currently, in the Czech Republic, as in other European countries, the average age of teachers is high (Lazarová 2011; Urbánek 2018), whereas in 1969 it was found that some teaching staff were very young, mainly in peripheral locations (Liška 1969).

Each age category has a specific role in the teaching staff (Lazarová 2009; Sekera 1995), and therefore in age-balanced teaching staff, intergenerational collaboration occurs (Novotný and Brücknerová 2014), which has a complementary effect (Urbánek 2018).

We are still encountering the increasing feminization of teaching staff. Already in 1969, when the degree of feminization in elementary school teachers reached $72 \%$, Liška described this problem as a thorny one in his research study. According to data from the Ministry of Education (2019), the degree of feminization of teaching 
staff at primary schools has reached $80.8 \%$, while there is a certain difference between the first and second stages of primary schools. The degree of feminization of teaching staff at the first stage of primary school is $91.8 \%$, while at the second stage of primary school it is $75.1 \%$. The high degree of feminization of teaching staff is not perceived favorably by experts, although its negative impact on pupils has not yet been proven by research (Urbánek 2018). In addition, the prevalence of women can lead to a greater stability of teaching staff, as men's turnover in education is higher than that of women (Lazarová et al. 2011). Řehulka and Řehulková (2001) also demonstrate that the masculinization of teaching staff would be a major problem as female teachers achieve more favorable professional characteristics. Nevertheless, it must be emphasized that the high degree of feminization of teaching staff, together with the imbalance of the female and male educational impact, does not affect pupils favorably (Bendl 2002).

\section{Social climate of teaching staff}

If we look at changes in the social climate of teaching staff over the years, as shown by the results of research surveys (Lašek 1995; Píšová 2004; Urbánek 2006; Nišponská, Urbánek 2007; Dvořák et al. 2010; Urbánek et al. 2014; Dvořák, Starý and Urbánek 2015; Urbánek et al. 2017), we can only agree with Urbánek (2018) that there are significant differences between individual Czech schools regarding different parameters of the social climate quality of the teaching staff. The differences between individual groups of teaching staff are mainly found in the openness of interpersonal relationships.

According to the results of a research study by Seberová (2012), $70 \%$ of teachers are satisfied with their relationships within the teaching staff and with their professional partners. They describe teacher-teacher relationships as open and friendly ( $81 \%$ of teachers), their teamwork as positive (73\%), and they value the friendly critical feedback (almost 70\%) and helpful feedback (66\%) that teachers provide to each other.

The social climate of the teaching staff is also influenced by its stability. Low staff turnover is a stabilizing factor in the functioning and development of the school (Vašutová and Urbánek 2010: 89). 
Teachers who have worked in a certain teaching staff for a long time are stabilizing factors in this group. The higher stability of the teaching staff is also related to more favorable social climate values (Urbánek and Koucký 2014).

\section{Research methodology}

The goal of the research was to map changes in some aspects of the teaching profession in the last thirty years according to the subjective perception of teachers-experts.

Based on the above-mentioned research goal, the following research questions were used:

RQ1: How have the relationships between fellow teachers changed over the last thirty years according to the subjective perception of teachers?

RQ2: How have communication and cooperation with pupils' parents changed over the last thirty years according to the subjective perception of teachers?

RQ3: How has the teacher-pupil relationship changed over the last thirty years according to the subjective perception of teachers?

The research goal was achieved with qualitative semi-structured interviews. All interviews were recorded and lasted 60-80 minutes. Two respondents (Lucie and Dáša) were interviewed twice; the first lasted 60 minutes and the second about 30 minutes to complete certain data. The interviews were written and coded using the open coding technique. In the second phase, the codes were categorized on the basis of content similarity (Švaříček, Šed’ová et al. 2007).

\section{Teachers-experts as respondents}

The respondents were teachers-experts who have been working as teachers for at least thirty years. Given the length of the respondents' experience, their perception of changes in education, which they have experienced throughout their teaching career, is highly subjective; their attitudes to change will have been influenced by their personal experience with a number of reforms (Mareš 2018). It has already been proven by researchers (Lazarová 2005) that teachers with long 
teaching experience show distrust and even a negative attitude toward reforms. Rusch and Perry (1993) also note that teachers with long teaching experience do not want to be actively involved in introducing innovations and reforms. The reason for this behavior may be, according to Lazarová (2005), the fact that teachers with many years of teaching experience fear that a change based on a reform effort is just the beginning of broader changes for which they will no longer have the necessary energy. According to Kariková (2015), teachers over fifty years of age are losing the need to be stimulated and to learn new things. Teachers at this age prefer routine and stereotypes, do not like learning new things, and have a negative relationship with introducing innovations and innovative methods into teaching.

\section{Research results}

\section{How the teacher-student relationship has changed}

In this area, three categories were identified on the basis of the open coding: low teacher authority, education as entertainment, and discipline problems.

\section{Low teacher authority}

In the opinion of the respondents, the teacher no longer commands as much respect in the eyes of pupils as they used to. This is because the current generation of young people differs in many important phenomena from the older generation. As the respondents are aware, a significant phenomenon that contributes to the difference between generations - some respondents even said that this phenomenon puts a border between generations - is represented by computerization, the transfer of life into virtual reality. Today's youth are also heavily influenced by the media and mass culture in which they grow up, resulting in a generational gap. For the same reasons, the respondents believe, the younger generation choose only people who are well-known in the media as their models of authority.

The respondents are aware of and negatively perceive the decreasing authority of teachers in today's society. This problem is related to the overall erosion of authority in today's society. The respondents 
state that pupils today are "much more daring with the teacher than they were before."

"Teaching is getting worse; teachers no longer have the authority among children that we used to have when I started (...) "When I started, pupils were afraid to admit at home that they had to stay in detention." (Lucie)

Because of the decreased authority of the teacher, the respondents perceive the work of the teacher to be more difficult and problematic than it previously was.

\section{Education as entertainment}

The respondents complain in their statements that the pupil's satisfaction is what is important today. There is a greater emphasis on pupils enjoying the learning and on the curriculum being taught in a playful way, which, according to some respondents, may have a negative impact on the amount of information pupils learn and above all on the pupils' discipline because, according to the respondents, the pupils are frequently not prepared for the partner approach that is associated with a playful form of learning and abuse it. According to Karolína's statement, teachers are regularly blamed by parents if their children do not like the teaching and do not want to learn. Also, according to the respondents' statements, the pupils themselves tell the teacher that they do not enjoy the class and understand this as the fault of the teacher.

"The teacher is frequently evaluated according to whether the students enjoy the lessons, whether the teacher can entertain them. The teacher is no longer required to teach pupils as much as possible, but to provide the knowledge in a playful way. This regularly has a negative impact on the level of knowledge and behavior of pupils. After all, pupils should learn that they will not always be able to do only what they enjoy. These days, a pupil will freely tell you that they do not want to do something because they do not enjoy it, because they do not like the teacher. When I started teaching, a pupil would not dare to say these things to the teacher." (Karolina) 


\section{Discipline problems}

In connection with the low authority of the teacher, the respondents report that young, beginner teachers especially face frequent disciplinary problems with children and noise in the classroom during teaching. The most common problem faced by teachers every day is the disorderly behavior of pupils, which may take on such intensity that it severely disturbs the teacher's work. The respondents report that teachers today must devote a disproportionate amount of time to bringing children into line. The surveyed teachers say that maintaining discipline in the classroom takes up undue effort, leading to stress, feelings of self-incompetence, and thoughts of whether to give up teaching.

"Teaching music education for primary schools in the 8th and 9th grades. This I truly consider my pedagogical 'purgatory." (Danka)

"When I start teaching a subject in a new grade or a new class, it always takes me some time to orientate. Working with classes where there are too many uncooperative pupils is very stressful." (Dominika)

\section{Changes in communication and cooperation with pupils' parents}

In this area, four categories were identified on the basis of the open coding: the weight of money, the parent as a client, parents "not siding with the teacher," and the liberal style of upbringing.

\section{Weight of money}

In this area, the respondents' statements show a degradation of the authority of the teacher, both in village and municipal schools. According to the respondents, the degradation of authority is related to the values of today's society, in which those with power and wealth are those wielding social prestige. Respondents regularly mention that in today's society we value people by their wealth and not by their moral and human qualities or abilities; we value people more by their power in society and by the possessions they have accumulated. Therefore, in the present society, the prestige and the social appreciation of the teaching profession have decreased. If the work of a teacher is financially undervalued, then society, the state, and the government show that the work of the teacher is not highly 
important. According to their testimonies, the respondents meet with the opinion that teachers are in their profession only because they have not found any better-paid jobs, which impacts the relations of parents and pupils with the teacher.

"Teaching is getting worse; the teacher no longer has the authority that I had when I started. Also, the situation in villages is not much better than in cities - today they are not villages in the true sense of the word; there are a lot of people in a village who became rich, moved there, built villas, and people do not know each other too much, and they do not cooperate with the school as much as they did before." (Lucie)

"In today's consumerist society, in a society focused on wealth and its accumulation, a society where people are valued according to how much they earn, how much money they have, what car they are driving and where they live, the teacher belongs to the lower class. At schools, there are also several children of parents who are very wealthy and who think they can handle anything with money, arrange everything, think that everything can be bought for money, everyone can be bribed. Today, when the teacher has a below-average salary, they have no authority with these parents, they despise you, take you as a lower-class, incompetent person." (Blanka)

\section{Parent as client}

According to the respondents, parents sometimes approach the school as customers who expect services rendered by the school, expecting the school to be responsible for their child's upbringing and grades. They expect the teacher to fully meet their child's needs and to develop their child, to devote all the care to them to understand everything, remember everything. They expect the teacher to "tailor the teaching to their child." And they also expect that their child's whole school attendance will proceed without any problems that they as parents would have to help solve, without any burden on them - everything will be solved by the teacher and the school.

"When I started, I taught in a small village... Relationships between parents and teachers were good, parents respected teachers; today, parents often perceive the school as serving them." (Lucie)

According to the respondents, parents place constant demands on the teacher; they think they know how the teacher can better develop their child and approach the child differently, and do not hesitate to 
demand that their requirements be met, some of them indiscriminately or aggressively.

"Parents consider themselves the self-elected pedagogy experts." (Karolina)

The respondents are confronted with parents who are completely uncritical of their children, whom they absolutely believe. Under any circumstance, these parents never see a problem in their child but in other classmates or, most frequently, in the teacher. If their child receives a bad grade, these parents are willing to go to the teacher and find the mistake in the teacher rather than in their own child.

"There are parents with views that if you complain about their child, there is no problem in their child, but that you have a problem. And if their child is failing at school, does not have good grades, it would be good to transfer them to another school because apparently the staff in this school are unable to understand their super intelligent, brilliant child." (Jana)

\section{Parents "not siding with the teacher"}

The respondents identically testify that it is currently the case that parents also question the teacher's views and knowledge in front of their child, thus further damaging the already crumbling authority of the teacher. This, according to the respondents, was not the case in the past.

"While previously parents might have thought anything about the teacher, they stood with them and didn't badmouth them in front of the child, they didn't talk about them critically at home." (Dása)

According to the respondents, not only do parents "not side with the teacher," they side with their child completely in any problem situation.

"There is an increasing number of parents who no longer see teachers as the definitive authority; it what is important for them is what their child tells them. They do not know the situation, they have only heard it from their child, but for them, the teacher is already a stupid cow who needs to be straightened out." (Lucie)

Dáša, in her testimony, introduces her own term, so-called "starter parents." They are parents who, when called to school, feel the need to "show the teacher their truth," the one they believe, the one their child told them. What the teacher has to say is frequently of 
no interest to them or is not believed. The respondent also says that these parents are verbally aggressive toward the teachers, coming up with profanities, threats, and gross insults.

"There's an increasing number of starter parents - those who start going after the teacher, knowing only what their child told them." (Dása)

\section{Liberal style of upbringing}

According to the respondents, the low authority of the teacher is also related to the upbringing of children in their families, in which the children are mostly raised by a liberal educational style or, at the present time, by the popular "non-bringing" style. The respondents describe that parents promoting this educational style believe that setting boundaries and using strict requirements can "hurt" the child in his/her development. According to the respondents, the parents preferring a liberal upbringing style connect it with the right path, at the end of which the children will grow to become confident and assertive personalities. These parents imagine that thanks to the "non-bringing" approach, their child will grow into a self-reliant, aspiring, responsible, creative, and assertive young person with clear goals and priorities, someone who knows what they want to do and what they want to achieve.

"And then we end up dealing with a spoiled, dependent, lazy brat, who is used to having everything done for them by their parents." (Karolina)

The respondents state that the parents who support a liberal educational style stand against criticism of their child's behavior by saying that their child is a personality. According to the respondents, in a classroom full of "personalities" - within the conception of some of today's parents - clashes and quarrels occur more regularly, and the class holds together less.

"Pupils are more confident, led at home to be assertive. Less tolerant to one another." (Dáša)

The respondents also report that there are situations in which "the school calls parents to take responsibility" and the parents do not want to solve the situation, see the child's impudent or aggressive behavior as their budding personality, and in no way want to interfere with this development. Sometimes the parents do not want to solve their child's problematic behavior according to the respondents - they 
apologize for the child with an "I know they are no saint" and wave it aside.

"Nowadays, the big problem is free upbringing, in which parents see their children as personalities and not as misbehavers; discipline is regarded as something harmful that can damage the child." (Jana)

\section{Changes in interpersonal relationships at work}

In this area, three categories were identified on the basis of the open coding: interpersonal relationships have not changed, small schools, and people caring about themselves.

\section{Interpersonal relationships have not changed}

In the statements of Lucie and Karolína, we meet with the view that interpersonal relationships have not changed, that cooperation between colleagues has stayed the same over the years, that everything is about specific people's individualities.

"The cooperation between colleagues has not changed, it is about the different individualities of people. Somerwhere the team is good and somewhere it is not, somewhere people help each other, are friends, and somewhere else they gossip and play dirty tricks on each other. That has always been and always will be." (Lucie)

"Somewhere the team is good and somewhere it is not." (Karolina)

\section{Small schools}

The respondents believe that interpersonal relationships are closely linked to the characteristics, size, and location of the school. In the statements of Lucie and Blanka, members of teaching staff in village schools and small schools are considered to be more cohesive, friendly, and cooperative.

"I was lucky enough to have a good team. I have always had great colleagues around me; we clicked, we helped each other, also the school management is nice too. I think it is also because I have always worked in small schools, in small groups of staff, where the teachers must get along because they really have no other choice. When you are in a team of four 
and hate each other, you make each other's lives miserable a lot sooner than you would in a big team of twenty." (Lucie)

"I think that in small schools the teachers must get along." (Blanka)

\section{People "caring about themselves"}

In the statements of Dáša and Dominika, however, we also see the opinion that relationships between colleagues are changing for the worse, that teachers and colleagues are no longer helping each other because everyone "cares about themselves." The respondents with this opinion are now afraid to go to a colleague to discuss a problem they are facing so as to not look incompetent and, moreover, to avoid management learning about it and begin perceiving them as incapable teachers.

"Human relationships are changing for the worse; everyone plays in their own sandbox, core teachers are afraid to openly deal with their failings." (Dáša)

"Cooperation among teachers is almost none, everyone is more or less looking out for themselves, which is a pity to me, but no one can be forced." (Dominika)

\section{Discussion}

In the present research study, the changes in some aspects of teachers' work since 1989 were mapped according to the subjective perceptions of female teachers-experts who have been working as teachers for more than thirty years. In the research survey, we dealt with the following areas: interpersonal relationships in the workplace, communication and cooperation between teachers and pupils' parents, and the teacher-pupil relationship.

The respondents are aware of and negatively perceive the declining authority of teachers in today's society, which corresponds with the statement of Strouhal (2013) that there is not only a crisis of teacher authority but of any authority today. According to Strouhal, the crisis of authority is a characteristic aspect of modern society, which slowly ceases to respect the traditional meaning of authority. The research study found out that, according to the respondents, the teacher's authority has degraded in the eyes of pupils, parents, and society as a whole. In their statements, the respondents mention that 
parents "do not team up with the teacher" and are fully on the side of their child whenever there is a problem at school; they also question the teacher's opinions and knowledge in front of the child, further dismantling the already crumbling authority of the teacher. This, according to the respondents, was not the case in the past. These research results correspond with the findings of Poláchová-Vaštátková and Rudnicki (2015), who underline the deepening crisis of the teaching profession, and with the statement of Strouhal (2013), who describes the decline of teachers' authority in society. The respondents perceive liberal education and "non-education" as problematic. A similar opinion is expressed by Mertin (2015), who states that the beginning of disrespect for authorities is caused by the influence of parents and their inconsistency when they do not insist that their requirements be met by the children and their misunderstanding of a free upbringing, resulting in a decline of respect for authority in children. Similarly, Mikulková (2015) describes that today's parents cease to be an authority for their children and try to be their friends instead, which leads to the children not respecting any authority. The respondents also repeatedly mention frequent disciplinary problems with children and the disruptive behavior of pupils in class, which can become so intense that it severely disrupts the teaching, and teachers now have to devote a disproportionate amount of time to disciplining children. The crisis of teacher authority, pupils' indiscipline, and negative attitudes toward school and learning are also described by Poláchová-Vaštátková and Rudnicki (2015), who state that the negative phenomena of society related to consumer culture, the detachment of young people from reality, and young people's desire for strong experiences also transfer to the school environment and have a negative impact on pupils' concentration and activity in class, on their motivation to learn, and on their generally unfriendly attitudes toward school and learning and their low willingness to engage in everyday life at school.

In the statements of Lucie and Karolína regarding relationships among the teaching staff, we come across the opinion that interpersonal relationships have not changed, that cooperation between colleagues has not changed over the years, that it is all based on the mindset of individual people. However, we also see the opinion, in the statements of Dáša and Dominika, that relations between colleagues 
are changing for the worse, that teachers-colleagues are no longer helping each other, and that everyone "takes care of themselves."This phenomenon is described in the research study by Poláchová-Vaštátková and Rudnicki (2015), who state that greater development of cooperation since 1989 has been hampered by the competitive environment in the education market, where each school guards its know-how and does not intend to share it with others. Cooperation between individual schools and individual teachers still exists, but it is not a phenomenon of massive scope; rather, it is spontaneous cooperation between several teachers or schools for the purpose of professional and methodological cooperation, which is frequently done for purely utilitarian reasons.

\section{Recommendations for teaching practice}

The research study found that the surveyed respondents feel low levels of authority and prestige in the eyes of students, parents, and society as a whole. Sochorová (2014) states that the prestige of the teaching profession is influenced by the following factors: importance for society, economic status, and level of knowledge. The work of a teacher in the Czech Republic has long been financially underestimated. The respondents frequently mention that in society today, we value people by their wealth and not by their moral and human qualities or abilities, so in today's society, there is a decline in the prestige of the social appreciation of the teaching profession. According to their statements, the respondents come across the opinion that teachers do their job only because they would not be employed in a better-paid position, which is reflected in the relationships of parents and students with teachers. The solution to this situation, in addition to a salary increase, which teachers have been fighting for for a long time, would be to introduce various benefits in the form of e.g. teacher flats, which are now being provided by municipalities and regions that face a shortage of teachers, or to introduce recruitment bonuses.

Low teacher authority is regularly associated with students' indiscipline, which is also mentioned in the respondents' statements. Beginner teachers are usually unprepared for these acts of indiscipline. The problem lies in inefficient and insufficient cooperation 
between pedagogical faculties or other faculties preparing teachers and kindergartens, primary schools and secondary schools, especially the small extent of pedagogical practice and insufficient contact with the real school environment that causes new teachers to not be sufficiently prepared for their future profession and face serious disciplinary problems in their classes at the beginning of their careers. This causes their early and untimely drop-out from the teaching profession. Therefore, all pedagogical and other faculties preparing future teachers must cooperate with a network of faculties and cooperating schools and other facilities to implement, firstly, a gradually increasing system of pedagogical practices in which each type of practice has its specific goal and content and, secondly, parallel teaching at the cooperating faculty or school as well as at the home faculty. This is because the high-quality, effective cooperation of the faculty with networks of other faculties and cooperating schools is one of the important paths leading to the development of the professionalization of the teaching profession.

In addition to the development of cooperation between universities, kindergartens, and primary and secondary schools, and the greater interconnection of theoretical and practical teaching, the career code would also be a useful tool to develop professionalization. Unfortunately, the draft amendment to the law did not pass through the lower parliament. According to the career code, beginner teachers would go through a so-called adaptation period, the aim of which would be their full adaptation to the current conditions and requirements of everyday teaching practice. During this period, the beginner teacher would be supported by the school management and assisted by an introductory teacher who would play the role of their mentor.

The low prestige of the teaching profession is also related to the problems currently faced by not only Czech but also foreign education systems, namely the aging of teachers and the lack of qualified teachers, especially in some regions and localities. In 2015, according to data from the Ministry of Education, 4,334 teachers were missing in education. With regard to the high average age of teachers at schools in the Czech Republic, we can expect a 10\% shortage of qualified teachers in education in the next few years. Moreover, in some fields such as physics and mathematics, due to the lack of 
qualified teachers, schoolmasters in many schools already employ teachers who do not meet the qualification requirements set by the law (Schejbalová 2017). We face a lack of interest in working in education, especially among young people. The Ministry of Education has proposed to introduce a career code since September 2016, which could increase the prestige of the teaching profession and offer young future teachers more attractive conditions in the field of financial evaluation. The career code would help to distinguish teachers in terms of the quality of their work with students, so it would function as a motivational tool for the professional development of teachers.

Another issue mentioned in the testimonies of the respondents is the lack of cooperation between teachers. In her research, Lazarová (2006) confirms that although most teachers consider themselves open to cooperation, the truth is that most teachers only work with a narrow group of colleagues whose members do not change. According to a questionnaire survey conducted by Kasíková and Dubec (2009), teachers need to be educated about cooperation and interested in it.

\section{Conclusion}

In this text, changes in some aspects of teacher work since 1989 have been mapped according to the subjective perception of female teachers-experts. The respondents were all female teachers-experts who have worked as teachers for at least thirty years. All the respondents currently work as primary school teachers.

The research dealt with the following areas: interpersonal relationships in the workplace, the communication and cooperation of teachers with pupils' parents, and the teacher-pupil relationship.

The respondents are aware of and negatively perceive the decreasing authority of the teacher in today's society. They mention that the authority of the teacher has been degraded in the eyes of pupils, parents, and society as a whole. In their testimonies, the respondents mention that parents do not "side with the teacher" and that parents of the pupils question the teacher's views and knowledge in front of the child, thus further damaging the already eroded authority of the teacher. According to the respondents, some parents not only "do not side with the teacher" but are fully on the side of their child in every 
school problem. This, according to the respondents, was not the case before. The respondents also perceive the liberal upbringing or the "non-bringing" approach and, above all, parents who "no longer see teachers as the definitive authority; it is important for them what their child tells them" as problematic.

In the statements of Lucie and Karolína about relationships in the teaching staff, we notice the view that interpersonal relationships have not changed, that cooperation between colleagues has not changed over the years, that everything is about the individualities of the people. However, we also see the opinion, in the statements of Dáša and Dominika, that relationships between colleagues are changing for the worse and that teachers-colleagues are no longer helping each other, but rather everyone "cares about themselves."

\section{Bibliography}

Bendl S. (2002). "Feminizace školství a její pedagogické konsekvence," Pedagogická orientace, vol. 12, no. 4, pp. 19-35.

Coch L., French J.R. Jr. (1948). "Overcoming resistance to change," Human Relations, vol. 1, no. 4, pp. 512-532.

Čapek, R. (2013). Ucitel a rodič, Praha: Grada.

Česká školní inspekce (2017). Tematická zpráva - využivání digitálních tech-

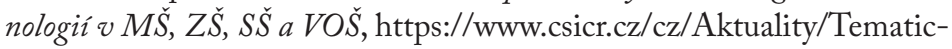
ka-zprava-Vyuzivani-digitalnich-technologii [access: 16.1.2020].

Dvořák D., Starý K., Urbánek, P. (2015). Škola v globální dobè. Promèny pèti českých základnich škol', Praha: Karolinum.

Dvořák D., Starý K., Urbánek P., Chvál M., Walterová E. (2010). Česká základni škola. Viceprípadová studie, Praha: Karolinum.

Fasnerová M. (2009). Kurikulární zmèny a jejich odrazy v klimatu školy z pobledu rodiču, Rigorózní práce, Univerzita Palackého v Olomouci, Pedagogická fakulta.

Hopkins D. (2001). School Improvement for Real, London, New York: Routledge.

Kariková S. (2015). "Učitel'ky primárného stupňa vzdelávania v biodromálnom kontexte," in B. Kasáčová, S. Kariková, B. Oelszlaeger-Kosturek (eds.), Učitel.' Teoretické a empirické kontexty primárnej edukácie, Cieszyn: Uniwersytet Śląski w Katowicach.

Kotásek J. (2004). "Budoucnost školy a vzdělávání," in E. Walterová (ed.), Úloha školy v rozvoji vzdèlanostim, Brno: Paido, pp. 441-484.

Lašek J. (1995). "Prvé skúsenosti s meraním klímy v škole a učitelskom zbore," Pedagogická revue, vol. 47, no. 1-2, pp. 43-50. 
Lazarová B. (2005). "Psychologické aspekty profesionálního rozvoje učitelů: rezistence vưči změně,” Pedagogika, vol. 55, no. 2, 102-118.

Lazarová B. (2009), "Vratké mosty porozumění. O učitelích dvou generací," in Kolektiv autorů, Pedagogická komunikace v didaktických, sociálních a filozofických souvislostech, Hradec Králové: Gaudeamus, pp. 38-46.

Lazarová B. et al. (2011). Pozdni sbèr. O práci zkušených učitelü, Brno: Paido.

Liška F. (1969), "K sociálně psychologické problematice učitelského sboru," Pedagogika, vol. 19, no. 3, pp. 425-440.

Lunenburg F.C. (2010), "Forces for and resistance to organizational change," National Forum of Educational Administration and Supervision Journal, vol. 27 , no. 4 , pp. 1-10.

Mareš J. (2018), “Odpor učitelů vůči změnám ve škole a školství,” Pedagogi$k a$, vol. 68 , no. 2, pp. 173-200

Ministerstvo školství, mládeže a tělovýchovy (2019). Hlavni výstupy z mimoráádněbo šetření ke stavu zajištěni výuky učiteli v $M \check{S}$, ZŠS SS̆ a VOŠ, http:// www.msmt.cz/ministerstvo/novinar/ministerstvo-zjistovalo-stav-ucitelu-v-regionalnim-skolstvi [access: 16.1.2020].

Nišponská M., Urbánek P. (2007), “Analýza klimatu učitelských sborů ZŠ: Kvalitativní sonda," in R. Jandová (ed.), Svèt vyychovy a vzdèláváni v reflexi pedagogickébo výzkumu, České Budějovice: PedF JČU, pp. 101-108.

Novotný P., Brücknerová K. (2014), "Intergenerational learning among teachers: Interaction perspective," Studia paedagogica, vol. 19, no. 4, pp. $45-79$.

Píšová M. (2004), "Klima školy z pohledu začínajícího učitele,” in S. Ježek (ed.), Psychosociální klima školy II, Brno: MSD, pp.128-151.

Poláchová-Vaštátková J., Rudnicki P., et al. (2015). Proměny české a polské pohranični školy poskytujici povinné základni vzděláni po roce 1989, Olomouc: Univerzita Palackého v Olomouci.

Průcha, J. (2002). Učitel. Současné poznatky o profesi, Praha: Portál.

Pugnerová M, Plevová I. (2010), "Pracovní spokojenost učitelů ZŠ s ohledem na vybrané factory,” in J. Šimíčková-Č́ižková (ed.) Psychologické aspekty v práci učitele, Ostrava: Universitas Ostraviensis.

Rabušicová M., Šed’ová K. Trnková K., Čiháček V. (2004), Škola a (versus) rodina, Brno: Masarykova univerzita.

Rusch E.A., Perry E.A. (1993). Resistance to change: Fact or stereotype, https:// eric.ed.gov/?id=ED360698 [access: 2.1.2020].

Řehulka E., Řehulková O. (2001). "Učitelky a učitelé," in E. Řehulka, O. Řehulková (eds.), Učitelé a zdravi 3, Brno: PÚ AV ČR, pp. 143-152.

Seberová A. (2012). "Profesní potřeby v dimenzi pracovní spokojenosti učitelů,” in T. Göbelová, A. Seberová, Profesiografické otázky učitelství, Ostrava: Universitas Ostraviensis.

Sekera J. (1995). "Konflikty v pedagogických sborech," Odborná výchova vol. 45, nos. 7-8, 9-10, pp. 63-64, 86-88. 
Straková J., Spilková V., Simonová J., Friedleandearová H., Hanzák T. (2013). "Názory učitelů základních škol na potřebu změn ve školním vzdělávání,” Orbis scholae, vol. 7, no. 1, pp. 79-100.

Švařiček R., Šedová K. (2007). Kvalitativní výzkum v pedagogických védách: pravidla hry, Praha: Portál.

Terhart E. (2013). "Teacher resistance against school reform: reflecting an inconvenient truth," School Leadership \& Management, vol. 33, no. 5, pp. $486-500$.

Urbánek P. (2006). "Klima učitelských sborů ZŠ: Empirická zjištění," in Kolektiv autorů, Současné metodologické prìstupy a strategie pedagogického výzkumu. Sbornik přispèvkiu 14. konference ČAPV. Plzeñ: PedF ZČU.

Urbánek P. (2012). “Učitelský sbor české základní školy," Orbis scholae, vol. 12, no. 3, pp. 11-30.

Urbánek P., Dvořák D., Starý K. (2014). "Dynamika sociálního klimatu učitelských sborů v době reformy,” Orbis scholae, vol. 8, no. 1, pp. 65-78.

Urbánek P., Koucký M. (2014). "Fluktuace učitelských sborů ve vícečetné př́padové studii ZŠ," paper presented at the 22nd ČAPV Annual Conference, Olomouc, September 2014.

Urbánek P., Picek J., Jursová J., Novotová J., Picková H., Rozkovcová A. (2017). "Výzkum učitelských sborů ZŠ: potenciál výběrových šetření, problematika výběru a vstupu do terénu," in I. Žlábková (ed.), Sbornik konference ČAPV, České Budějovice: JČU.

Vašutová J., Urbánek P. (2010). “Učitelé v současné základní škole: hledání mezi změnou a stabilitou," Orbis scholae, vol. 4, no. 3, pp. 79-91.

Voda J. (2012). "Učitelské sbory," paper presented at the Konference školského management, 7 June 2012.

\section{ADDRESS FOR CORRESPONDENCE}

Lucie Zormanová

University of Silesia in Katowice

Institute of Pedagogy

e-mail: lucie.zormanova@us.edu.pl 